\title{
Gebukt onder regels en toezicht
}

\author{
André Bindenga
}

De accountant van vandaag kan alleen zijn beroep uitoefenen als hij op de hoogte is van vele wetten en regels. Bovendien moet hij rekening houden met toezichthouders uit binnen- en buitenland. Op zich is dit begrijpelijk gezien de ontwikkelingen in de laatste decennia op het gebied

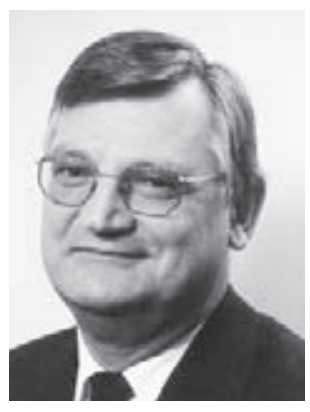
van de financiële verslagge-

ving. Helaas zijn er ook negatieve aspecten verbonden aan de vele voorschriften. Een belangrijk punt is in dit opzicht dat regels elkaar tegenspreken of tenminste niet gelijkluidend zijn.

Als voorbeeld noem ik het onderwijs in de accountancy. In internationaal verband zijn er de zogenaamde 'education standards' van de International Federation of Accountants. Daarnaast heeft een aantal Europese beroepsorganisaties een voorstel ontwikkeld voor een gemeenschappelijke basisinhoud voor de opleiding tot accountant. Dit voorstel wordt aangeduid als de 'common content'.

Zowel in de standards als in de common content wordt uitgegaan van een brede opleiding en een variëteit van onderwerpen. Men krijgt sterk de indruk dat de opleiding niet gericht is op de accountant als controleur van jaarrekeningen.

De Achtste Europese Richtlijn geeft ook weer op welke wijze de opleiding tot accountant gestalte moet krijgen. Hierbij is de controlerend accountant wel het uitgangspunt. Ook in Nederland zullen de voorschriften voor de inhoud van de accountantsopleiding

Prof.dr. A.J. Bindenga RA is emeritus hoogleraar accountancy, oud-voorzitter van de Raad van Bestuur van Ernst \& Young en oud-voorzitter van het Koninklijk NIvRA. in belangrijke mate worden bepaald door de eisen die gesteld worden aan de accountant als wettelijk controleur. Het hoofdstuk over de accountantsopleiding zal immers worden geschrapt uit de Wet op de Registeraccountants en worden vervangen door enkele bepalingen in de Wet Toezicht Accountantsorganisaties en een Algemene Maatregel van Bestuur.

Hoe moet men hiermee omgaan?

Ik heb het idee dat de universitaire accountantsopleidingen zich prepareren op een curriculum dat opleidt voor de accountant als wettelijk controleur. Dit houdt in dat geen breed vakkenpakket wordt aangeboden.

Aan de andere kant is men zich binnen de Nederlandse beroepsorganisatie aan het bezinnen over de toekomst van het onderwijs in de accountancy. Deze organisatie streeft naar pluriformiteit en het is niet onlogisch dat men denkt aan een brede opleiding. Maar de beroepsorganisatie is geen onderwijsinstelling meer, dus is de vraag gerechtvaardigd hoe dit streven in het onderwijs aan de universiteiten tot uitdrukking moet komen. De universiteiten zijn immers geneigd zich te beperken tot een opleiding als wettelijk controleur.

De bovenstaande situatie is een voorbeeld waarbij voorschriften door verschillende organen kunnen leiden tot verschillende interpretaties.

Bij het toezicht ziet men een overeenkomstige situatie. Vroeger was de uitvoering van de wetgeving in handen van de overheid, die direct toezicht hield op de financiële markt. Nu zijn tussen de overheid en de markt onafhankelijke toezichthouders geplaatst. De toezichthouders zijn mede ingesteld omdat het systeem faalde.

De verslaggevingsschandalen, de onvolledige informatieverstrekking aan potentiële beleggers en afnemers van financiële producten, de imperfecte werking van de financiële markt en de vertrouwenscrisis ten opzichte van financiële dienstverleners hebben het ontstaan van toezichthouders bevorderd. 
Over het algemeen maakt men een onderscheid in gedragstoezicht en prudentieel toezicht. De eerste vorm van toezicht richt zich vooral op de integriteit van marktpartijen terwijl de tweede vorm van toezicht met name de solvabiliteit van financiële instellingen bewaakt. In sommige landen zijn beide soorten toezicht in één hand, in andere landen ziet men verschillende organen. Hierdoor ontstaan ook verschillen in de uitvoering van het toezicht.

Ook hiervan een voorbeeld. De accountant van een onderneming die genoteerd is aan effectenbeurzen in de Verenigde Staten en in Europa zal moeten voldoen aan onafhankelijkheidsvoorschriften. In de Verenigde Staten zijn deze voorschriften nogal 'rule-based', terwijl men in Europa de 'principle based'-benadering voorstaat.

Een accountantsorganisatie die wereldwijd opereert moet voor de accountants binnen de organisatie regels samenstellen. Bij de 'Big Four' ziet men dat deze regels Amerikaans georiënteerd zijn, terwijl dit voor de meerderheid van de accountants in Europa en Azië niet nodig is omdat die vrijwel nooit te maken hebben met Amerikaanse ondernemingen.

De beroepsbeoefenaar van vandaag gaat soms gebukt onder regels en toezicht. Hoe dit invloed zal hebben op de accountancy in de toekomst is een open vraag. Maar hierover een volgende keer. 